\title{
ANALISIS PENGARUH CASH FLOW DAN RETURN ON \\ INVESTMENTTERHADAP RETURN SAHAM \\ PADA PERUSAHAAN MANUFAKTUR YANG MASUK DALAM \\ INDEKS LQ45 PERIODE TAHUN 2011-2014
}

Oleh :

\author{
Nia Tresnawaty, SE.,M.Ak \\ dan \\ Yunia Asmanah Kurniasih
}
Fakultas Ekonomi Program Studi Akuntansi
Universitas Satya Negara Indonesia

\begin{abstract}
ABSTRAK
Penelitian ini dilakukan untuk melihat pengaruh dari cash flow dan return on investment terhadap return saham pada perusahaan manufaktur yang terdaftar di Bursa Efek Indonesia yang secara berturut-turut masuk ke dalam indeks LQ45 selama periode tahun 2011 hingga 2014. Variabel yang digunakan dalam penelitian ini adalah Cash Flow, Return On Investment, dan Return Saham. Penelitian ini adalah penelitian kuantitatif dengan desain deskriptif yang pengolahan datanya menggunakan SPSS versi 22 .

Populasi dalam penelitian ini adalah 45 perusahaan dan pemilihan sampel mengunakan metode puposive sampling yang menghasilkan 6 perusahaan manufaktur sebagai objek penelitian. Data dari penelitian ini adalah data sekunder yang terdiri dari cash flow dan return on investment sebagai variabel independen dan return saham sebagai sebagai variabel dependen yang dipublikasikan melalui website www.idx.co.id. Teknik analisis data mengunakan analisis linear berganda untuk mengetahui pengaruh cash flow dan return on investment terhadap return saham.

Dari hasil uji t variabel cash flow (X1) tidak memiliki pengaruh terhadap return saham (Y). Dengan perolehan nilai -t hitung lebih besar dari -t tabel $(-0,168>-2,080)$ dengan tingkat signifikansi 0,868 lebih besar dari $0,05(>5 \%)$. Begitu juga dengan variabel return on investment (X2) tidak memiliki pengaruh terhadap Y nilai perusahaan dengan perolehan angka $t$ hitung lebih kecil dari t tabel $(0,471<2,080)$ dengan tingkat signifikansi 0,643 lebih besar dari 0,05 (>5\%). Dan hasil uji $\mathrm{F}$ atau secara simultan diperoleh bahwa variabel cash flow dan return on investment secara bersama-sama tidak memiliki pengaruh terhadap return saham, dengan perolehan nilai $\mathrm{F}$ hitung lebih kecil dari $\mathrm{F}$ tabel $(0,175<4,325)$ dengan tingkat signifikansi 0,841 lebih besar dari 0,05 $(>5 \%)$.

Saran yang dapat diberikan adalah investor perlu memperhatikan faktor lain dalam melakukan investasi dalam perusahaan manufaktur, selain Cash Flow dan Return On Investment terdapat faktor lain yang berpengaruh terhadap return saham dan penelitian lanjutan diharapkan dapat menambah periode pengamatan dan variabel lain.

Kata kunci : Cash Flow (CF), Return On Investment (ROI), dan Return Saham (RS
\end{abstract}




\section{PENDAHULUAN}

Laporan keuangan merupakan salah satu sumber utama informasi keuangan yang sangat penting bagi sejumlah pemakai dalam pengambilan keputusan ekonomi.Dalam laporan keuangan perusahaan dapat digunakan para investor untuk memprediksi sekuritas saham. Sekuritas saham sangat dipengaruhi oleh besarnya aliran imbal hasil (return) yang akan diperoleh perusahaan di masa mendatang. Agar keputusan investasi dapat memuaskan investor, maka diperlukan adanya suatu analisis sekuritas dalam upaya melakukan penetapan harga efek yang wajar.

Laporan arus kas merupakan salah satu laporan dari laporan keuangan yang dapat berpengaruh terhadap perilaku investor. Salah satu tujuan dari pelaporan keuangan menurut Statment of Financial Accounting Concept (SFAC) No. 1 adalah menyediakan informasi bagi investor dan kreditor maupun pemakai potensial lainnya dalam pengambilan keputusan investasi dan kredit, serta dalam penaksiran mengenai jumlah, waktu, dan ketidakpastian dari penerimaan arus kas netto prospektif. Disamping itu arus kas juga berguna untuk meneliti kecermatan dari taksiran arus kas masa depan yang telah dibuat sebelumnya dan dalam menentukan hubungan antara profitabilitas dan arus kas bersih serta dampak perubahan harga (IAI, 2004). Suatu perusahaan apabila arus kasnya baik maka akan dapat menarik perhatian invetor untuk berinvestasi. Sehingga dapat dikatakan, bahwa informasi arus kas merupakan informasi penting yang dibutuhkan investor untuk mengetahui kemampuan perusahaan dalam menghasilkan kas bagi investor, maupun untuk membayar kewajiban perusahaan yang jatuh tempo serta kegiatan operasional perusahaan sehari-hari.

(Hariono Sinaga, 2010) mengatakan dalam penelitiannya bahwa ada pengaruh yang signifikan dan negative antara Arus Kas Operasional terhadap Expected Return Saham secara parsial; tidak ada pengaruh yang signifikan antara Arus Kas Investasi terhadap Expected Return Saham secara parsial; tidak ada pengaruh yang signifikan antara Arus Kas Pendanaan terhadap Expected Return Saham secara parsial; ada pengaruh yang signifikan dan positif antara Laba Kotor terhadap Expected Return Saham secara parsial; dan ada pengaruh yang signifikan dan positif antara Ukuran Perusahaan (Size) terhadap Expected Return Saham secara parsial.

Arsul Ardiansyah, Muhammad Ali, Yansor Djaya (2011) mengatakan dalam penelitiannya arus kas operasi dan return oninvestment memberikan pengaruh positif terhadap returnsaham. Arus kas investasi dan arus kas pendanaan tidak memberikan pengaruh terhadap return saham.

Dari hasil penelitian di atas terlihat adanya research gap atau perbedaan hasil penelitian, dimana penelitian oleh Hariono Sinaga (2010) memperoleh bahwa ada pengaruh yang signifikan dan negative antara Arus Kas Operasional terhadap ReturnSaham, sedangkan penelitian yang dilakukan oleh Arsul Ardiansyah, Muhammad Ali, Yansor Djaya (2011) mengatakan dalam penelitiannya arus kas operasi dan return oninvestment memberikan pengaruh positif terhadap return saham.

Berdasarkan pernyataan-pernyataan di atas, maka penelitian ini mengambil judul "ANALISIS PENGARUH CASH FLOW DAN RETURN ON INVESTMENT TERHADAP RETURN SAHAM PADA PERUSAHAAN MANUFAKTUR YANG MASUK DALAM INDEKS LQ45 PERIODE TAHUN 2011-2014“. 


\section{Perumusan Masalah}

Dari uraian diatas, permasalahan dalam penelitian ini dirumuskan sebagai berikut :

1. ApakahCash Flow berpengaruh terhadap return saham?

2. Apakah ROI return of investment berpengaruh terhadap return saham?

3. Apakah Cash Flow dan ROI secara bersamaan berpengaruh terhadap return saham?

\section{Tujuan Penelitian}

Adapun tujuan dari penelitian ini adalah sebagai berikut:

1. Untuk membuktikan adanya pengaruh arus kas terhadap return saham.

2. Untuk mengetahui pengaruh ROI return on investment terhadap return saham.

3. Untuk mengetahui pengaruh aruskas dan ROI secara bersamaan terhadap return saham.

\section{LANDASAN TEORI \\ Pengertian Pasar Modal}

Di dalam Undang-Undang Pasar Modal No. 8 Tahun 1995, pengertian pasar modal dijelaskan dengan lebih spesifik sebagai kegiatan yang bersangkutan dengan Penawaran Umum dan Perdagangan Efek, perusahaan publik yang berkaitan dengan Efek yang diterbitkannya, serta lembaga dan profesi yang berkaitan dengan Efek.

Selanjutnya menurut Munir Fuadi (2001:10) Istilah pasar modal dipakai sebagai terjemahan dari istilah Capital Market. Yang berarti suatu tempat atau system bagaimana caranya dipenuhi kebutuhan-kebutuhan dana untuk capital suatu perusahaan, merupakan pasar tempat orang membeli dan menjual surat efek yang dikeluarkan. Sementara itu Undang-Undang Pasar Modal No. 8 Tahun 1995 Pasal 1 angka 13 memberi pengertian kepada pasar modal sebagai suatu kegiatan yang berkenaan dengan penawaran umum dan perdagangan efek, perusahaan publik yang berkaitan dengan efek yang diterbitkannya, serta lembaga dan profesi yang berkaitan dengan efek.

\section{Manfaat Pasar Modal}

Pekembangan ekonomi suatu negara sangat ditentukan oleh lembaga perbankan dan keuangan termasuk di dalamnya pasar modal. Menurut Sunariah dalam bukunya Pengetahuan Pasar Modal (2003 : 9) bahwa manfaat pasar modal, yaitu :

a. Menyediakan sumber pembiayaan (jangka panjang) bagi dunia usaha sekaligus memungkinkan alokasi sumber dana secara optimal.

b. Memberikan wahana investasi bagi investor sekaligus memungkinkan upaya diversifikasi.

c. Menyediakan leding indikator bagi trend ekonomi negara.

d. Penyebaran kepemilikan perusahaan sampai lapisan masyarakat menengah.

e. Penyebaran kepemilikan, keterbukaan dan profesionalisme, menciptakan iklim berusaha yang sehat.

f. Menciptakan lapangan kerja / profesi yang menarik.

g. Memberikan kesempatan memiliki perusahaan yang sehat dan memiliki prospek.

\section{Arus Kas}

Laporan arus Kas merupakan salah satu laporan keuangan pokok, disamping neraca dan laporan laba rugi.Jadi, untuk pelaporan kepada pihak di luar perusahaan, laporan ini wajib dibuat. Para pemakai laporan ingin mengetahui bagaimana perusahaan menghasilkan dan menggunakan kas dan setara kas. Jika digunakan dalam kaitannya dengan laporan keuangan yang lain, laporan arus kas dapat memberi informasi tentang 
perubahan aktiva bersih perusahaan, struktur keuangan (termasuk likuiditas dan solvabilitas), dan kemampuan untuk mempengaruhi jumlah serta waktu arus kas dalam kedaan menghadapai keadaan dan peluang. Disamping itu, arus kas dapat memberikan informasi tentang kemampuan perusahaan dalam menghasilkan kas dan setara kas sehingga memungkinkan para pemakai laporan keuangan mengembangkan model untuk menilai dan membandingkan nilai sekarang arus kas masa depan dari berbagai perusahaan. Informasi arus kas historis sering digunakan sebagai indikaor dari jumlah, waktu dan kepastian arus kas masa depan. Laporan arus kas pada dasarnya mengikhtisarkan sumber kas yang tersedia untu melakukan kegiatan perusahaan serta penggunaannya selama suatu periode tertentu.

Suatu laporan yang merinci arus dana sangat penting bagi perusahaan. Sebab dengan demikian dapat diketahui bagaimana perusahaan memperoleh dan menggunakan dana. Sayangmya perubahan dana tersebut kurang dapat ditunjukkan oleh laporan keuangan yang selama ini dipelajari, yakni neraca dan laoran laba rugi. Neraca hanya menunjukkan sumber dan penggunaan dana erusahaan pada saat terntentu. Tetapi ia tidak dapat menunjukkan perubahan yang terjadi dalam komposisi yang terdapat didalamnya. Betul juga bahwa apabila neraca pada suatu saat tertentu dibandingkan dengan neraca yang sama pada waktu yang berbeda akan dapat dilihat perubahan diantara keduanya. Tetapi ia belum dapat menjelaskan secara terinci sebab-sebab perubahan tadi. (Soemarso:2010)

\section{Tujuan dan Kegunaan Laporan Arus Kas}

PSAK No.2 paragraf 1 (IAI:2007) menyatakan bahwa tujuan laporan arus kas adalah sebagai berikut :

"Informasi arus kas suatu perusahaan berguna bagi para pemakai laporan keuangan sebagai dasar untuk menilai kemampuan perusahaan dalam menghasilkan kas dan setara kas, dan menilai kebutuhan perusahaan untuk menggunakan arus kas tersebut. Dalam proses pengambilan keputusan ekonomi, para pemakai lapoan keuangan perlu melakukan evalusai terhadap kemampuan perusahaan dalam menghasilkan kas dan setara kas serta kapasitas perolehannya. Tujuan pernyataan ini adalah memberi informasi historis mengenai perubahan kas dan setara kas dari suatu perusahaan melalui laporan arus kas yang mengklasifikasikan arus kas berdasarkan aktivitas operasi, investasi maupun pendanaan (financing) selama suatu periode akuntansi."

Laporan arus kas dapat digunakan untuk (PSAK No. 2) :

a. Laporan arus kas dapat memberikan informasi yang memungkinkan para pengguna untuk mengevaluasi perubahan dalam aset bersih perusahaan, struktur keuangan (termasuk likuiditas dan solvabilitas) dan kemampuan mempengaruhi jumlah serta waktu arus kas dalam rangka adaptasi dengan perubahaan keadaan dan peluang.

b. Informasi arus kas berguna untuk menilai kemampuan perusahaan dalam menghasilkan kas dan setara kas dan memungkinkan para pengguna mengembangkan model untuk menilai dan membandingkan 10 nilai sekarang dari arus kas masa depan (future cash flows) dari berbagai perusahaan.

c. Informasi arus kas juga meningkatkan daya banding pelaporan kinerja operasi berbagai perusahaan karena dapat meniadakan pengaruh penggunaan perlakuan akuntansi yang berbeda terhadap transaksi dan peristiwa yang sama.

d. Informasi arus kas historis sering digunakan sebagai indikator dari jumlah, waktu, dan kepastian arus kas masa depan. 
e. Informasi arus kas berguna untuk meneliti kecermatan dari taksiran arus kas masa depan yang telah dibuat sebelumnya dan dalam menentukan hubungan antara profitabilitas dan kas bersih serta dampak perubahan harga.

\section{ROI ( Return On Investment )}

Return on investment (ROI) merupakan salah satu rasio yang digunakan untuk mengukur laba perusahaan. Menurut Ang (1997) dalam Ardiansyah (2011), ROI merupakan rasio terpenting diantara rasioprofitabilitas lain jika digunakan untuk memprediksi return saham. ROI merupakan rasio antara laba sesudah pajak atau net income after tax terhadap total assets. ROI yang semakin tinggi akan meningkatkan daya tarik investor, sehingga harga saham relatif meningkat, demikian pula return saham akan meningkat. Dengan meningkatnya ROI maka kinerja saham ditinjau dari sisi profitabilitas semakin baik. Dengan meningkatnya ROI maka akan menambah daya tarik investor untuk menanamkan dananya ke dalam perusahaan. Sehingga harga saham perusahaan akan meningkat.

Disamping itu, hasil pengembalian invesasi (ROI) menunjukkan produktivitas dari seluruh dana perusahaan, baik modal pinjaman maupun modal sendiri. Semakin kecil (rendah) rasio ini, semakin kurang baik, demikian pula sebaliknya.Artinya rasio ini digunakan untuk mengukur efektivitas dari keseluruhan operasi perusahaan. (Syahrial \& Purba: 2013)

Dengan demikian ROI diharapkan berhubungan positif terhadap return saham. Hal ini dikuatkan oleh penelitian yang dilakukan oleh Asrul Ardiansyah, M. Ali, \& Yansor Djaja (2011) yang menunjukkan bahwa ROI signifikan positif terhadap return saham. Penelitian tersebut kontradiktif terhadap penelitian yang dilakukan Ruriana Ulfa (2011) yang mengatakan bahwa ROI tidak signifikan terhadap return saham. Dan Dyah Kumala Trisaeni (2007) dalam penelitiannya mengatakan bahwa ROI tidak berpengaruh terhadap return saham.

\section{Return Saham}

Menurut Jogiyanto (2010) return merupakan hasil atau keuntungan yangdiperoleh pemegang saham sebagai hasil dari investasinya. Sedangkan pengertianreturn (tingkat kembalian) menurut Robert Ang (1997: 20-2) yaitu tingkatkeuntungan yang dinikmati oleh pemodal atas suatu investasi yang dilakukannya.Tanpa adanya tingkat keuntungan yang dinikmati dari suatu investasi, tentunyainvestor (pemodal) tidak akan melakukan investasi. Jadi setiap investasi baik jangka pendek maupun jangka panjang mempunyai tujuan utama mendapatkankeuntungan yang disebut sebagai return baik langsung maupun tidak langsung.

Komponen return terdiri dari 2 jenis yaitu current income (pendapatanlancar) dan capital gain (keuntungan selisih harga). Current income merupakankeuntungan yang diperoleh melalui pembayaran yang bersifat periode sepertipembayaran bunga deposito, bunga obligasi, dividen dan sebagainya.Disebutsebagai pendapatan lancar, maksudnya adalah keuntungan yang diterima biasanyadalam bentuk kas atau setara kas, sehingga dapat diuangkan secara cepat, sepertibunga / jasa giro dan dividen tunai.Dan yang setara kas adalah saham bonus ataudividen saham yaitu dividen yang dibayarkan dalam bentuk saham dan dapat dikonversi menjadi uang kas.

Komponen kedua dari return adalah capital gain, yaitu keuntungan yangditerima karena adanya selisih antara harga jual dengan harga beli saham darisuatu instrumen investasi. Capital gain sangat tergantung dari harga pasarinstrumen investasi, yang 
berarti bahwa instrumen investasi harus diperdagangkandi pasar. Dengan adanya perdagangan maka akan timbul perubahan nilai suatuinstrumen investasi yang memberikan capital gain. Besarnya capital gaindilakukan dengan analisis return historis yang terjadi pada periode sebelumnya,sehingga dapat ditentukan besarnya tingkat kembalian yang diinginkan (expectedreturn).Expected return merupakan return (tingkat kembalian) yang diharapkanoleh investor atas suatu investasi yang akan diterima pada masa yang akan datang.Faktor yang mempengaruhi return suatu investasi meliputi faktor internalperusahaan dan faktor eksternal. Faktor internal perusahaan meliputi kualitas danreputasi manajemen, struktur permodalan, struktur hutang, tingkat laba yangdicapai dan kondisi intern lainnya di dalam perusahaan.

\section{Pengaruh Arus kas dengan Return Saham}

Dalam Sinaga (2010), Arus kas melaporkan arus kas masuk dan arus kas keluar yang utama dari suatu perusahaan selama satu periode. Tujuan utama laporan arus kas adalah memberikan informasi tentang penerimaan kas dan pembayaran kas suatu entitas selama periode tertentu. Tujuan lain adalah memberikan informasi kepada kreditor, investor dan pemakai lainnya dalam menentukan kemampuan perusahaan untuk menimbulkan arus kas bersih positif dimasa yang akan dating, menentukan kemampuan perusahaan menyelesaikan kewajibannya seperti melunasi hutang kepada kreditor, menentukan alasan tentang terjadinya perbedaan antara laba bersih dan dihubungkan dengan pembayaran dan penerimaan kas serta menentukan pengaruh transaksi kas pembelanjaan dan investasi bukan kas terhadap posisi keuangan perusahaan.

Laporan arus kas melaporkan arus kas melalui tiga jenis transaksi yaitu (1) arus kas dari aktivitas operasi, yaitu arus kas dari transaksi yang mempengaruhi laba bersih; (2) Arus kas dari aktivitas investasi, yaitu arus kas dari transaksi yang mempengaruhi investasi dari aktiva lancer dan (3) Arus kas dari aktivitas pendanaan, yaitu arus kas dari transaksi yang mempengaruhi ekuitas dan utang perusahaan.

\section{Pengaruh Arus Kas Operasi dengan Return Saham}

Aktivitas operasi adalah aktivitas penghasil utama pendapatanperusahaan (principal revenue activities) dan aktivitas lain yang bukanmerupakan aktivitas investasi dan pendanaan, umumnya berasal dari transaksidan peristiwa lain yang mempengaruhi penetapan laba atau rugi bersih, danmerupakan indikator yang menentukan apakah dari operasi perusahaan dapatmenghasilkan kas yang cukup untuk melunasi pinjaman, memeliharakemampuan operasi perusahaan, membayar dividen dan melakukan investasibaru tanpa mengandalkan pada sumber pendanaan dari luar.

Livnat dan Zarowin (1990) dalam Ninna Daniati (2006) yang mengujikomponen arus kas menemukan bukti bahwa komponen arus kas mempunyaihubungan yang lebih kuat dengan expected return saham disbanding hubungan total arus kas dengan return. Hasil penelitian yang dilakukan olehNinna Daniati (2006) yang memperoleh hasil tidak adanya pengaruh yangsignifikan antara arus kas operasi terhadap expected return saham.

Secara teori, semakin tinggi arus kas operasional perusahaan makasemakin tinggi kepercayaan investor pada perusahaan tersebut, sehinggasemakin besar pula nilai expected return saham.Dan sebaliknya, semakinrendah arus kas operasional perusahaan maka semakin kecil kepercayaaninvestor pada perusahaan tersebut, sehingga semakin kecil pula nilai expectedreturn saham. 


\section{Pengaruh Arus Kas Investasi dengan Return Saham}

Aktivitas investasi adalah aktivitas yang menyangkut perolehan ataupelepasan aktiva jangka panjang (aktiva tidak lancar) serta investasi lain yangtidak termasuk dalam setara kas, mencakup aktivitas meminjamkan uang danmengumpulkan piutang tersebut serta memperoleh dan menjual investasi dan aktiva jangka panjang produktif. Aktivitas investasi mencerminkanpengeluaran kas sehubungan dengan sumber daya yang bertujuan untukmenghasilkan pendapatan dan arus kas masa depan.

Arus kas investasi, Miller dan Rock (1985) dalam Livnat dan Zarowin (1990) menyatakan, ketidakrelevanan arus kas investasi dengan return. Umumnya peningkatan arus kas investasi meningkat atau positif dikarenakan tingkat return yang tinggi diharapkan dari pengumuman investasi. Namun, investor harus mengantisipasi investasi modalnya karena mungkin tidak ada hubungan antara return dan investasi. Leland dan Pyle (1977) dalam Livnat dan Zarowin (1990) menyatakan bahwa peningkatan proporsi kepemilikan melalui investasi saham minoritas akan berdampak positif terhadap return tetapi peningkatan saham perusahaan tidak dibarengi dengan implikasi positif dari arus kas.

\section{Pengaruh Arus Kas Pendanaan dengan Return Saham}

Arus kas pendanaan, Miller dan Modigliani (1961) dalam Livnat dan Zarowin (1990) menyatakan bahwa komponen arus kas pendanaan tidak harus memberikan kontribusi untuk asosiasi arus kas yang tak terduga terhadap return. Ada kebijakan dividen perusahaan yang mengatur pembiayaan penerbitan utang, saham biasa dan preferen. Miller dan Rock (1985) dalam Livnat dan Zarowin (1990) menjelaskan bahwa arus kas pendanaan dari efek signaling dan disaggregate dengan return karena menjelaskan penerbitan utang yang mempengaruhi harga saham, saham biasa, saham preferen, dan dividen sehingga tidak ada keterkaitannya dengan return.

Berdasarkan teori-teori yang telah dikemukakan di atas, dapat disimpulkan bahwa Informasi nilai arus kas operasi yang terdapat dalam laporan arus kas perusahaan menunjukkan kemampuan perusahaan dalam memperoleh kas secara internal untuk melakukan pembayaran atas kewajibannnya sehingga akan mempengaruhi minat pemegang saham untuk menanamkan modalnya sehingga pada akhirnya akan berpengaruh terhadap harga saham yang diterbitkan suatu perusahaan.

\section{Pengaruh Return On Investment (ROI) dengan Return Saham}

Robert Ang (1997) return on investment merupakan rasio terpenting diantara rasio profitabilitas yang ada untuk memprediksi return saham, semakin tinggi ROI, semakin tinggi pula return saham. Nilai ROI yang semakin tinggi menunjukkan suatu perusahaan semakin efisien dalam memanfaatkan aktivanya untuk memperoleh laba, sehingga nilai perusahaan dan return meningkat (Brigham 2001 dalam Triyono 2000).

Secara teori, apabila semakin tinggi ROI Return on investment maka semakin tinggi pula return saham. Dan begitupun sebaliknya, semakin rendah ROI Return on investment maka akan semakin kecil pula retun sahamnya.

\section{METODE PENELITIAN}

\section{Jenis Data}

Jenis data yang digunakan dalam penelitian ini adalah data sekunder. Data sekunder adalah data yang diperoleh secara tidak langsung melalui media perantara (diperoleh dan dicatat oleh pihak lain). Data tersebut dapat diperoleh dari lembaga 
atau keterangan serta melalui studi pustaka yang ada hubungannya dengan masalah yang dihadapi dan dianalisis. Data yang dipergunakan adalah :

1. Data harga saham pada saat penutupan (closing price)

Sumber data : Indonesia Capital Market Directory tahun 2011, 2012, 2013 dan 2014.

2. Data laporan arus kas.

Sumber data : Laporan Keuangan emiten tahun 2011, 2012, 2013 dan 2014.

\section{Metode Pengumpulan Data}

Metode pengumpulan data yang digunakan terutama dengan cara studi dokumentasi, yaitu merupakan suatu cara yang digunakan untuk memperoleh data dengan menganalisis informasi yang didokumentasikan dalam bentuk tulisan atau bentuk-bentuk lain. Data diperoleh dari Indonesia Capital Market Directory dan data laporan keuangan untuk tahun 2011 - 2014. Selain itu peneliti juga mengumpulkan data melalui website www.idx.co.id untuk mendapatkan laporan keuangan perusahaan yang bersangkutan.

\section{Populasi dan Sampel}

Dalam penelitian ini, populasi yang dimaksud adalah perusahaan manufaktur yang mencatatkan sahamnya di BEI periode 2011, 2012, 2013 dan 2014. Sampel dalam penelitian ini adalah perusahaan manufaktur yang terdaftar di BEI dan dibatasi pada perusahaan manufaktur yang menyajikan laporan keuangan per 31 Desember untuk tahun 2011, 2012, 2013 dan 2014. Pemilihan sampel pada perusahaan manufaktur yang terdaftar di BEI berdasarkan beberapa alasan dengan teknik pengambilan sampel menggunakan purposive sampling dan pemilihan sample berdasarkan pertimbangan (judgment sampling), yaitu merupakan tipe pemilihan sample secara tidak acak yang informasinya diperoleh dengan menggunakan pertimbangan tertentu dengan kriteria :

a. Perusahaan manufaktur yang berturut-turut tercatat selama periode pengamatan 2011, 2012, 2013 dan 2014.

b. Perusahaan manufaktur yang telah menerbitkan dan mempublikasikan laporan keuangan auditannya per 31 Desember 2011, 2012, 2013 dan 2014.

c. Perusahaan manufaktur yang sahamnya terdaftar di indeks LQ 45 selama tahun 2011, 2012, 2013, dan 2014.

\section{Definisi Operasional}

Penelitian ini dirancang sebagai suatu penelitian empiris yaitu untuk menguji hipotesis yang diajukan.Penelitian ini menggambarkan pengaruh atau hubungan variabel independen terhadap variabel dependen. Variabel dependen adalah variabel yang tidak bisa berdiri sendiri, dalam penelitian ini variable dependennya adalah :

\section{a. Return Saham}

Jenis return yang digunakan dalam penelitian ini adalah return realisasi atau sering disebut actual return yang merupakan capital gain yaitu selisih antaraharga saham periode saat ini dengan harga saham pada periode sebelumnya dibagi dengan harga saham periode sebelumnya. Actual return masing-masing saham selama periode peristiwa dirumuskan sebagai berikut : (Jogiyanto, $2000: 108$ )

Rit $=$ Pit - Pit -1 
Pit-1

Dimana :

Rit $=$ Return saham satu pada periode $t$

Pit $=$ Harga saham satu pada periode $t$

Pit- 1 = Harga saham satu pada periode $t-1$

Sedangkan variabel independen adalah variabel yang bisa berdiri sendiri (variabel bebas), dalam penelitian ini variabel independennya adalah :

\section{b. Total arus kas}

Total Arus kas operasi pada penelitian ini diproksi menggunakan total selisih antara arus kas operasi, arus kas investasi dan arus kas pendanaan.

\section{c. Arus kas operasi}

$$
\mathrm{TOTCF}=\mathrm{CFO}+\mathrm{CFI}+\mathrm{CFP}
$$

Arus kas operasi merupakan aktivitas penghasil utama perusahaan dan aktivitas lain selain investasi dan pendanaan. Arus kas operasi pada penelitian ini diproksi menggunakan selisih antara arus kas operasi masuk dengan arus kas operasi keluar.

d. Arus kas investasi

$$
\mathrm{CFO}=\mathrm{CFO} \text { Masuk }-\mathrm{CFO} \text { Keluar }
$$

Arus kas investasi merupakan aktivitas yang menyangkut perolehan atau pelepasan aktiva jangka panjang (aktiva tidak lancar) serta investasi lain yang tidak termasuk dalam setara kas, mencakup aktivitas meminjamkan uang dan mengumpulkan piutang serta memperoleh dan menjual investasi dan aktiva jangka panjang. Arus kas investasi pada penelitian ini diproksi menggunakan selisih antara arus kas investasi masuk dengan arus kas investasi keluar.

\section{e. Arus kas pendanaan}

$$
\mathrm{CFI}=\mathrm{CFI} \text { Masuk }- \text { CFI Keluar }
$$

Arus kas operasi merupakan aktivitas yang mengakibatkan perubahan dalam jumlah serta komposisi ekuitas dan pinjaman perusahaan.Arus kas operasi pada penelitian ini diproksi menggunakan selisih antara arus kas pendanaan masuk dengan arus kas pendanaan keluar.

$$
\mathrm{CFP}=\text { CFP Masuk }- \text { CFP Keluar }
$$

\section{f. Return on investment (ROI)}

Return On Investment (ROI) adalah ratio uang yang diperoleh atau hilang pada suatu investasi, relative terhadap jumlah uang yang diinvestasikan. Jumlah uang yang diperoleh atau hilang tersebut dapat disebut bunga atau laba/rugi.ROI juga dikenal sebagai tingkat laba (rate of profit) atau hasil suatu investasi pada saat ini, masa lampau atau prediksi di masa mendatang.Atau bahasa sederhananya ROI merupakan pengembalian keuntungan atas investasi.

\section{HASIL PENELITIAN}

Pembahasan Hasil Analisa Data

Analisis Statistik Deskriptif

$$
\begin{gathered}
\text { ROI }=\text { Earning After Tax } \\
\text { Total Asset }
\end{gathered}
$$


Analisis statistic deskriptif memberikan gambaran atau deskripsi suatu data yang dilihat dari nilai rata-rata (mean), standar deviasi, varian, maksimum, minimum, sum, range, kurtosis, dan sweakness (kemenccengan disstribusi). (Ghazali, 2006:19) Hasil analisis statistik deskriptif dari penelitian ini dapat dilihat dari table berikut:

\section{Tabel 4.1. Analisis Statistik Deskriptif Descriptive Statistics}

\begin{tabular}{|l|r|r|r|r|r|r|}
\hline & & Minimu & Maximu & & \multicolumn{1}{c|}{ Std. } \\
& \multicolumn{1}{|c|}{$\mathrm{N}$} & $\mathrm{m}$ & $\mathrm{m}$ & \multicolumn{1}{c|}{ Sum } & \multicolumn{1}{c|}{ Mean } & \multicolumn{1}{c|}{ Deviation } \\
\cline { 2 - 7 } & Statistic & Statistic & Statistic & Statistic & \multicolumn{1}{c|}{ Statistic } & Statistic \\
\hline RS & 24 & .0113035 & .7122990 & 4.9201839 & .205007663 & .1547138902 \\
CF1 & 24 & .21 & 1.26 & 13.52 & .5635 & .24869 \\
ROI1 & 24 & .00 & .45 & 6.98 & .2906 & .10074 \\
Valid N & 24 & & & & & \\
(listwise) & & & & & & \\
\hline
\end{tabular}

Pada table 4.1. Dari hasil analisis deskriptif diatas dapat dilihat variabel Return Saham (Y) dengan jumlah data $(\mathrm{N})$ sebanyak 24 mempunyai nilai return saham rata-rata sebesar 0.205007663 dengan nilai return saham minimal 0.0113035 dimana nilai minimal tersebut terdapat pada PT. Astra Argo Lestari,Tbk di tahun 2014 dan nilai return saham maksimal 0.7122990 yang terdapat pada PT. Gudang Garam,Tbk di tahun 2014, sedangkan nilai standar deviasinya sebesar 0.1547138902. Variabel CF1 (X1) dengan jumlah data $(\mathrm{N})$ sebanyak 24 mempunyai presentase rata-rata sebesar 0.5635 dengan nilai Cash Flow transfromasi minimal sebesar 0.21 dengan nilai data 0.04258584 dimana nilai minimal tersebut terdapat pada PT. Semen Gresik, Tbk di tahun 2013 dan nilai Cash Flow transformasi maksimal sebesar 1.26 dengan nilai data 1.57684133 yang terdapat pada PT. Indofood Sukses Makmur,Tbk di tahun 2013 sedangkan nilai standar deviasinya sebesar 0.24689. Dan yang terakhir adalah ROI1(X2) dengan jumlah data $(\mathrm{N})$ sebanyak 24 memiliki nilai rata-rata return on investment transformasi sebesar 0.2906 dengan nilai ROI transformasi minial sebesar 0.00 dengan nilai data 0.0440223 dimana nilai minimal tersebut terdapat di PT. Indofood Sukses Makmur,Tbk di tahun 2013 dan nilai maksimal transformasi sebesar 0.45 dengan nilai data 0.2448495 yang terdapat pada PT. Astra Argo Lestari,Tk di tahun 2011, sedang nilai standar deviasiny sebesar 0.10074 .

\section{Uji Normalitas}

Uji normalitas digunakan untuk mengetahui apakah populasi data berdistribusi normal atau tidak.Uji ini biasanya digunakan untuk mengukur data berskala ordinal, interval, atauun rasio.Jika analisis menggunakan metode paarametrik, maka persyaratan normalitas harus terpenuhi, yaitu data berasal dari distribusi yang normal.Jika data tidak beristribusi normal, maka metode alternative yang dapat digunakan adalah statistic non parametric. Hasil uji normalitas data dapat dilihat pada histogram dan grafik sebagai berikut: 


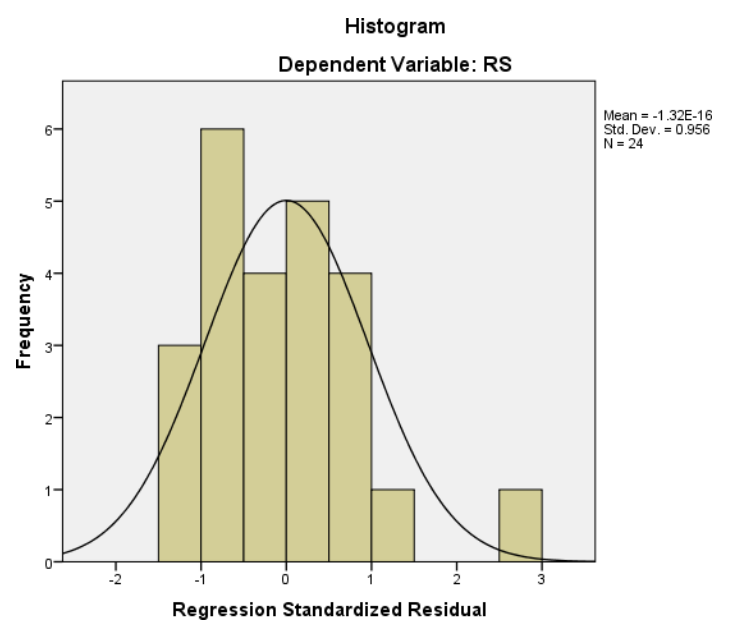

\section{Gambar 4.1 Histogram Uji Normalitas}

Pada gambar 4.1 dapat dilihat bahwa histogram hasil uji normalitas diatas menunjukkan hasil yang simetris atau tidak melenceng ke kiri ataupun ke kanan.Sehingga dapat dikatakan bahwa histogram diatas telah memenuhi asumsi uji normalitas.

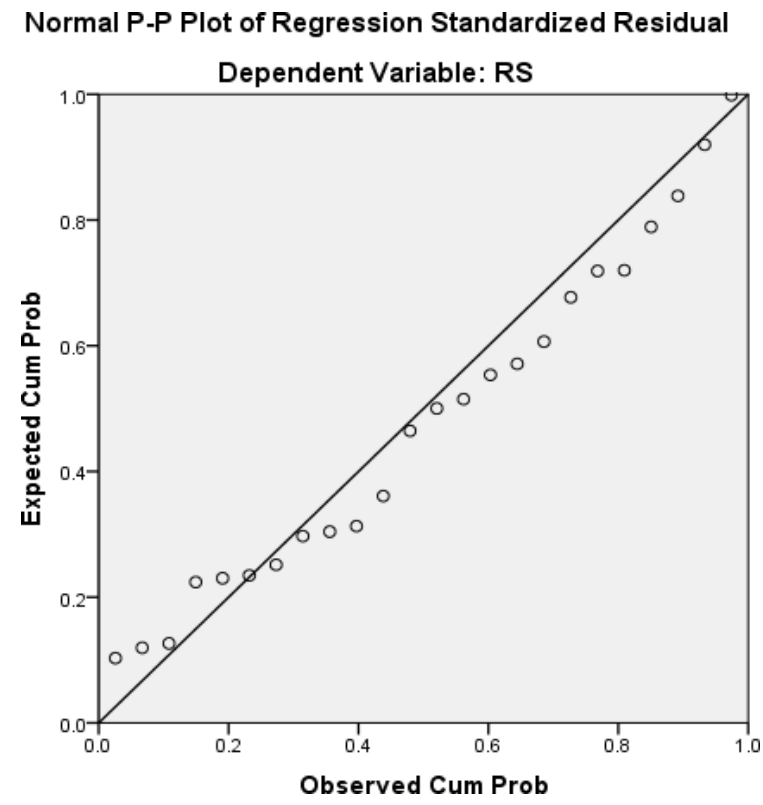

\section{Gambar 4.2 Grafik Normal P-P Plot}

Pada prinsipnya normalitas dapat dideteksi dengan melihat penyebaran data (titik) pada sumbu diagonal dari grafik. Dengan dasar pengambilan keputusan:

- Jika menyebar disekitar garis diagonal dan mengikuti arah garis diagonal menunjukkan pola distribusi normal, maka model regresi memenuhi asumsi normalitas.

- Jika data menyebar jauh dari diagonal dan atau tidak menikuti arah garis diagonal tidak menunjukkan pola distribusi normal, maka model regresi tidak memenuhi asumsi normalitas.

Dengan melihat tampilan pada grafik normal P-P Plot terlihat bahwa titik-titik (data) menyebar di sekitar garis diagonal dan penyebaranya tidak jauh dari garis 
diagonal.Maka dari grafik P-P Plot ini dapat disimpulkan bahwa menunjukkan model regresi telah memenuhi asumsi normalitas.

Untuk lebih menginterprestasikan, maka peneliti melakukan uji normalitas lainnya dengan menggunakan uji statistik Kormogolov-Smirnov.

Hasil uji normalitas juga dapat dilihat pada hasil table berikut ini:

Tabel 4.3. Tabel Uji Normalitas

One-Sample Kolmogorov-Smirnov Test

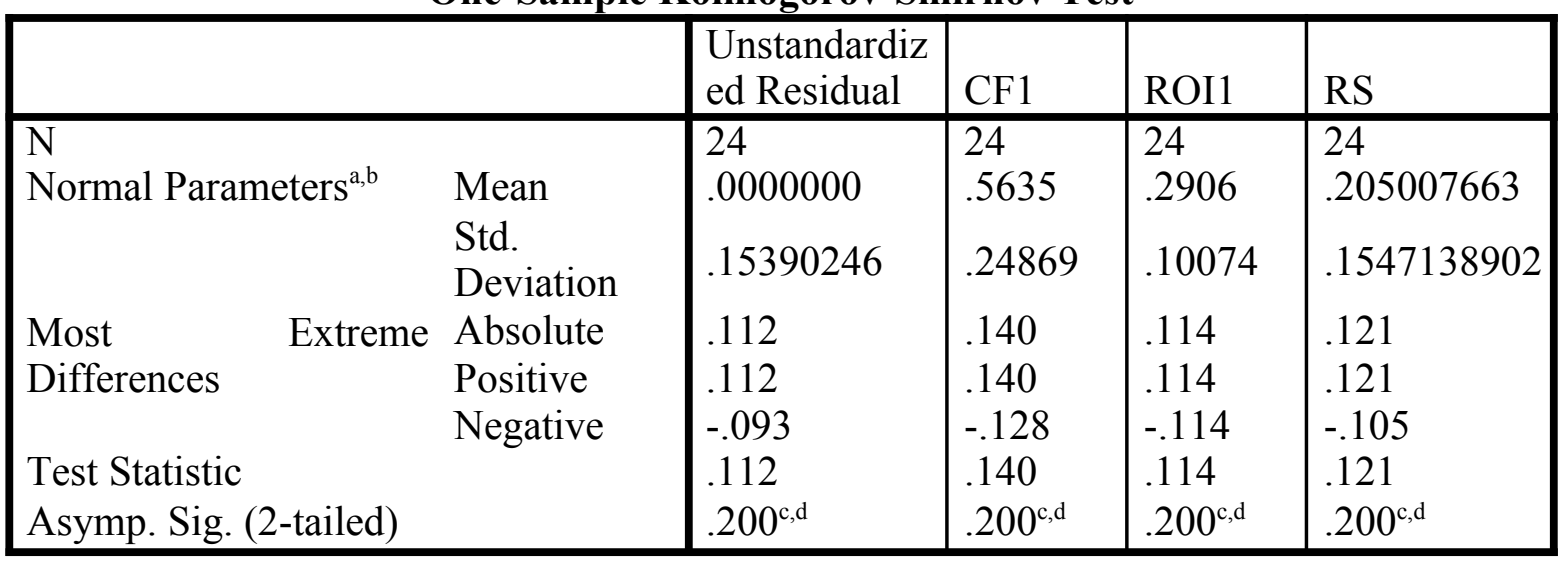

a. Test distribution is Normal.

b. Calculated from data.

c. Lilliefors Significance Correction.

d. This is a lower bound of the true

significance. Hipotesis:

$\mathrm{H}_{\mathrm{o}}=$ Populasi berdistrbusi normal

$\mathrm{H}_{\mathrm{a}}=$ Populasi tidak berdistribusi dengan normal

Kriteria pengujian;

- Jika signifikansi $>0,05$, maka $\mathrm{H}_{\mathrm{o}}$ diterima.

- Jika signifikansi $<0,05$, maka $\mathrm{H}_{\mathrm{a}}$ ditolak.

Kesimpulan:

$>$ Dari output pada table 4.2 diatas dapat dilihat bahwa nilai hasil uji normalitas non parametric one-sampe Kolmogorov test pada kolom unstandardized residual menunjukkan nilai kormologov-smirnov $Z$ (test statistic) sebesar 0.112 dan nilai Asymp. Sig. (2-tailed) sebesar $0.200(0.200>0.005)$, maka $\mathrm{H}_{\mathrm{o}}$ diterima.

$>$ Dari output pada table 4.2 diatas dapat dilihat bahwa nilai hasil uji normalitas non parametric one-sampe Kolmogorov test pada CF1 (X1) menunjukkan nilai kormologov-smirnov Z (test statistic) sebesar 0.140 dan nilai Asymp. Sig. (2-tailed) sebesar $0.200(0.200>0.005)$, maka $\mathrm{H}_{\mathrm{o}}$ diterima. Jadi dapat disimpulkan bahwa distribusi data cash flow tersebut berdistribusi normal.

$>$ Dari output pada table 4.2 diatas dapat dilihat bahwa nilai hasil uji normalitas non parametric one-sampe Kolmogorov test pada ROI1 (X2) menunjukkan nilai kormologov-smirnov Z (test statistic) sebesar 0.114 dan nilai Asymp. Sig. (2-tailed) sebesar $0.200(0.200>0.005)$, maka $\mathrm{H}_{\mathrm{o}}$ diterima. Jadi dapat disimpulkan bahwa distribusi data ROI tersebut berdistribusi normal.

$>$ Dari output pada table 4.2 diatas dapat dilihat bahwa nilai hasil uji normalitas non parametric one-sampe Kolmogorov test pada RS (Y) menunjukkan nilai kormologov-smirnov Z (test statistic) sebesar 0.121 dan nilai Asymp. Sig. (2-tailed) sebesar $0.200(0.200>0.005)$, maka $\mathrm{H}_{\mathrm{o}}$ diterima. Jadi dapat disimpulkan bahwa distribusi data return saham tersebut berdistribusi normal. 


\section{Uji Asumsi Klasik \\ Uji Multikolinearitas}

Multikolinearitas adalah keadaan dimana terjadi hubungan linier yang sempurna atau mendekati sempurna antar variabel independen dalam model regresi.Uji multikolinearitas digunakan untuk mengetahui ada atau tidaknya hubungan linear antar variabel independen dalam model regresi. (Duwi Priyatno, 2010:81)

Tabel 4.3 Uji Multikolinearitas (coefficients)

Coefficients $^{\text {a }}$

\begin{tabular}{|c|c|c|c|c|c|c|c|}
\hline \multirow[b]{2}{*}{ Model } & \multicolumn{2}{|c|}{$\begin{array}{c}\text { Unstandardized } \\
\text { Coefficients }\end{array}$} & \multirow{2}{*}{\begin{tabular}{l} 
Standardize \\
d \\
Coefficients \\
\multicolumn{1}{c}{ Beta }
\end{tabular}} & \multirow[b]{2}{*}{$\mathrm{t}$} & \multirow[b]{2}{*}{ Sig. } & \multicolumn{2}{|c|}{$\begin{array}{c}\text { Collinearity } \\
\text { Statistics }\end{array}$} \\
\hline & B & Std. Error & & & & $\begin{array}{c}\text { Toleranc } \\
\mathrm{e}\end{array}$ & VIF \\
\hline $1 \quad$ (Constant & .169 & .111 & & 1.532 & .140 & & \\
\hline CF1 & -.025 & .146 & -.040 & -.168 & .868 & .850 & 1.176 \\
\hline ROI1 & .170 & .362 & .111 & .471 & .643 & .850 & 1.176 \\
\hline
\end{tabular}

a. Dependent Variable: RS

Pengambilan keputusan:

a. Melihat nilai Tolerance

- Tidak terjadi Multikolinearitas, jika nilai Tolerance lebih besar dari 0.10

- Terjadi Multikolinearitas, jika nilai Tolerance lebih kecil atau sama dengan 0.10

b. Melihat nilai VIF

- Tidak terjadi Multikolinearitas, jika nilai VIF lebih kecil dari 10.

- Terjadi Multikolinearitas, jika nilai VIF lebih besar atau sama dengan 10.

Pada table 4.3 uji multikolinearitas diatas menunjukkan nilai tolerance untuk CF1 dan ROI1 sebesar 0.850 , artinya nilai tolerance dari keduanya lebih dari 0.10 yang berarti tidak terdapat masalah multikolinearitas.Sedangkan untuk nilai VIF dari CF1 dan ROI1 sebesar 1.176 yang memiliki nilai kurang dari 10 artinya tidak terdapat pula masalah multikolinearitas antar variable ini.

\section{Uji Heteroskedastisitas}

Uji Heterokedastisitas bertujuan menguji apakah dalam model regresi terjadi ketidaksamaan variane dari residual satu pengamatan ke pengamatan yang lain. Jika variance dari residual satu pengamatan ke pengamatan lain tetap, maka disebut Homoskedastisitas dan jika berbeda disebut Heteroskedastisitas. Model regrei yang lebih baik adalah yang Homoskesdastisitas atau tidak terjadi Heteroskedastisitas. (Ghazali, 2006:125) 


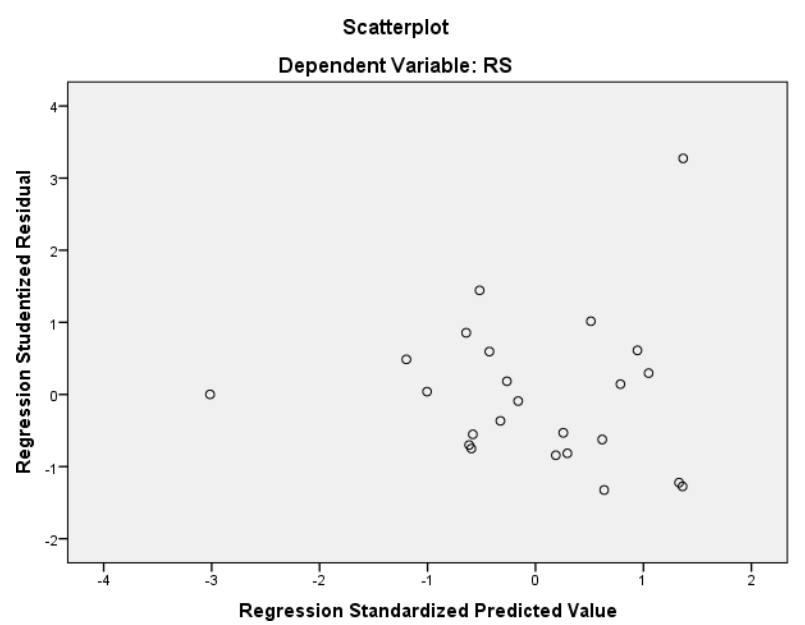

Gambar 4.3 Uji Heteroskedastisitas

Dari grafik scatterplots terlihat bahwa titik-titik menyebar secara acak serta tersebar baik dia atas maupun di bawah angka 0 pada sumbu Y. Hal ini dapat disimpulkan bahwa tidak terjadi heteroskedastisitas pada model regresi, sehingga model regresi layak dipakai untuk memprediksi RETURN SAHAM berdasarkan masukan variabel independen CASH FLOW DAN RETURN ON INVESTMENT.

Hasil uji Heteroskedastisitas juga dapat dilihat melalui table berikut ini:

Tabel 4.4 Uji Heteroskedastisitas

\begin{tabular}{|c|c|c|c|c|c|}
\hline \multicolumn{6}{|c|}{ Correlations } \\
\hline & & & $\begin{array}{c}\text { Unstandar } \\
\text { dized } \\
\text { Residual }\end{array}$ & CF1 & ROI1 \\
\hline \multirow[t]{3}{*}{$\begin{array}{l}\text { Spearman's } \\
\text { rho }\end{array}$} & $\begin{array}{l}\text { Unstandardized } \\
\text { Residual }\end{array}$ & $\begin{array}{l}\text { Correlation } \\
\text { Coefficient } \\
\text { Sig. (2-tailed) } \\
\text { N }\end{array}$ & $\begin{array}{r}1.000 \\
24\end{array}$ & $\begin{array}{r}.277 \\
.191 \\
24\end{array}$ & $\begin{array}{r}-.063 \\
.768 \\
24\end{array}$ \\
\hline & CF1 & $\begin{array}{l}\text { Correlation } \\
\text { Coefficient } \\
\text { Sig. (2-tailed) } \\
\mathrm{N}\end{array}$ & $\begin{array}{r}.277 \\
.191 \\
24 \\
\end{array}$ & $\begin{array}{r}1.000 \\
24 \\
\end{array}$ & $\begin{array}{r}.312 \\
.138 \\
24 \\
\end{array}$ \\
\hline & ROI1 & $\begin{array}{l}\text { Correlation } \\
\text { Coefficient } \\
\text { Sig. (2-tailed) } \\
\text { N }\end{array}$ & $\begin{array}{r}-.063 \\
.768 \\
24\end{array}$ & $\begin{array}{r}.312 \\
.138 \\
24\end{array}$ & 1.000 \\
\hline
\end{tabular}

Dari output Correlations di atas, dapat diketahui korelasi antara CF1 dengan Unstandardized Residual menghasilkan nilai signifikan (2-tailed) 0.191 dan korelasi antara ROI1 dengan Unstandardized menghasilkan nilai signifikan (2-tailed) 0.768 . Karena kedua nilai signifikan korelasi lebih dari 0.05, maka dapat disimpulkan bahwa pada model regresi tidak ditemukan adanya masalah heteroskedastisitas. 


\section{Uji Autokolerasi}

Uji Autokolerasi bertujuan untuk menguji apakah dalam model regresi linear ada kolerasi antara kesalahan pengganggu pada periode $\mathrm{t}-1$ (sebelumnya).Jika terjadi kolerasi, maka dinamakan ada problem autokolerasi. (Imam Ghazali, 2006:99)

\section{a. Uji Durbin - Watson (DW test)}

Uji Durbin-Watson hanya digunakan untuk autokolerasi tingkat satu (first order autocoleration) dan mensyaratkan adanya intersept (konstanta) dalam model regresi dan tidak ada variabel lagi diantara variable independen. Hipotesis yang akan diui adalah:

H0 : Tidak ada autokolerasi ( $\mathrm{r}-0$ )

HA : Ada autokolerasi $(r \neq 0)$

Tabel 4.5 Uji autokolerasi (DW test)

Model Summary ${ }^{\mathrm{b}}$

\begin{tabular}{|l|c|r|r|r|r|}
\hline Model & R & R Square & $\begin{array}{c}\text { Adjusted R } \\
\text { Square }\end{array}$ & $\begin{array}{c}\text { Std. Error of } \\
\text { the Estimate }\end{array}$ & $\begin{array}{c}\text { Durbin- } \\
\text { Watson }\end{array}$ \\
\hline 1 & $.102^{\mathrm{a}}$ & .010 & -.084 & .1610645022 & 2.464 \\
\hline
\end{tabular}

a. Predictors: (Constant), ROI1, CF1

b. Dependent Variable: RS

Dari table 4.5 diatas uji autokolerasi dengan menggunakan DW test menunjukkan nilai DW sebesar 2.464 , sedangkan dari table DW dengan signifikansi 0.05 dan jumlah data $(\mathrm{n})=24$ dan $\mathrm{k}=2$ (k adalah jumlah variabel independen) diperoleh nilai (dl) sebesar 1.188 dan nilai (du) debesar 1.546. Oleh karena nilai DW 2.464 lebih besar dari batas atas (du) 1.546 dan kurang dari 4 - 1.546 (4-dl), maka dapat disimpulkan bahwa kita tidak bisa menolak H0 yangmenyatakan bahwa tidak ada kolerasi negative (dilihat dari table keputusan) atau dapat disimpulkan tidak terdapat autokolerasi.

b. Uji autokolerasi dengan menggunakan Run Test

Runs test sebagai bagian dari statistic non-parametrik dapat pula digunakan untuk menguji apakah antar residual terdapat korelasi yang tinggi. Dan run test inni juga digunakan untuk melihat apakah data residual terjadi secara random atau tidak (sistematis).

Tabel 4.6 Uji Autokolerasi ( Runs test )

\begin{tabular}{|l|r|}
\hline \multicolumn{2}{|c|}{ Runs Test } \\
\hline \multicolumn{1}{|c|}{$\begin{array}{l}\text { Unstandardiz } \\
\text { ed Residual }\end{array}$} \\
\hline Test Value ${ }^{\mathrm{a}}$ & -.00710 \\
\hline Cases $<$ Test Value & 12 \\
\hline $\begin{array}{l}\text { Cases }>=\text { Test } \\
\text { Value }\end{array}$ & 12 \\
\hline Total Cases & 24 \\
\hline Number of Runs & 18 \\
\hline Z & 1.878 \\
\hline $\begin{array}{l}\text { Asymp. Sig. (2- } \\
\text { tailed) }\end{array}$ & .060 \\
\hline
\end{tabular}


Dari hasil outout SPSS menunjukkan bahwa nilai test ada;ah 1.878 dengan problabiitas 0.060 signigfikan pada 0.05 yang berarti hipotesis nol diterima.Sehingga dapat disimpulkan bahwa residual bersifat random atau tidak terjadi autokolerasi anatr nilai residual.

\section{Uji Regresi Linear Berganda}

Analisis regresi liniear berganda adalah hubungan secara liniear antara dua atau lebih variabel independen dengan variabel dependen.Analisis ini untuk memprediksi nilai dari variabel dependen apabila nilai variabel independen mengalami kenaikan atau penurunan, dan untuk mengetahui arah hubungan antara variabel independen dengan variabel dependen apakah masing-masing variabel independen berhubungan positif atau negative. (Duwi Priyatno, 2010:61)

Hasil output analisis regresi linear berganda dapat dilihat pada table di bawah ini:

Tabel 4.7 Analisis Regresi Liniear Berganda

Coefficients $^{\mathrm{a}}$

\begin{tabular}{|c|c|c|c|c|c|c|}
\hline \multirow{2}{*}{\multicolumn{2}{|c|}{ Model }} & \multicolumn{2}{|c|}{$\begin{array}{c}\text { Unstandardized } \\
\text { Coefficients }\end{array}$} & \multirow{2}{*}{$\begin{array}{c}\text { Standardized } \\
\text { Coefficients } \\
\text { Beta } \\
\end{array}$} & \multirow[b]{2}{*}{$\mathrm{t}$} & \multirow[b]{2}{*}{ Sig. } \\
\hline & & B & Std. Error & & & \\
\hline \multirow[t]{3}{*}{1} & (Constant) & .169 & .111 & & 1.532 & .140 \\
\hline & CF1 & -.025 & .146 & -.040 & -.168 & .868 \\
\hline & ROI1 & .170 & .362 & .111 & .471 & .643 \\
\hline
\end{tabular}

a. Dependent Variable: RS

Dari hasil output spss diatas dapat diketahui persamaan regresinya sebagai berikut:

$$
\begin{aligned}
& Y^{\prime}=a+b_{1} X_{1}+b_{2} X_{2} \\
& Y^{\prime}=0.169+(-0.025) X_{1}+ \\
& 0.170 X_{2} Y^{\prime}=0.169-0.025 X_{1}+
\end{aligned}
$$

$$
\begin{aligned}
& \mathrm{Y}^{\prime}=\text { Return } \\
& \text { Saham } \mathrm{a}= \\
& \text { konstanta } \\
& \mathrm{b}_{1}, \mathrm{~b}_{2}=\text { koefisien } \\
& \text { regresi } \mathrm{X}_{1}=\mathrm{CF}(\%)
\end{aligned}
$$

Persamaan regresi diatas dapat dijelaskan sebagai berikut:

- Konstanta sebesar 0.169; artinya jika CFO (X1) dan ROI (X2) nilai nya adalah 0 , maka nilai return saham (Y) adalah 0.169 .

- Koefisien regresi vsrariabel CF (X1) sebesar -0.025; artinya jika CF mengalami kenaikan 1\%, maka return saham (Y) akan mengalami penurunan sebesar 0.025 dengan asumsi variabel independen lainnya tetap. Koefisien bernilai negative artinya terjadi hubungan negative antara $\mathrm{CF}$ dengan return saham, semakin naik cash flow maka return saham akan semakin menurun, begitupun sebaliknya.

- Koefisien regresi variabel ROI (X2) sebesar 0.170: artinya jika ROI mengalami kenaikan 1\%, maka return saham (Y) akan mengalami peningkatan sebesar 0.170 dengan asumsi variabel independen lain nilainya tetap. Koefisien bernilai positif artinya terjadinya hubungan positif antara Return On Investment dengan Return Sham, semakin naik ROI maka nilai return saham akan meningkat pula, begitupun sebaliknya. 
Analisis Kolerasi Ganda (R)

Analisis kolerasi ganda digunakan untuk mengetahui hubungan antara dua atau lebih dua atau lebih variabel independen terhadap variabel dependen secara serentak.

Tabel 4.8 Analisis Korelasi Ganda (R)

Model Summary ${ }^{\mathrm{b}}$

\begin{tabular}{|l|c|r|r|r|}
\hline Model & R & R Square & $\begin{array}{c}\text { Adjusted R } \\
\text { Square }\end{array}$ & $\begin{array}{c}\text { Std. Error of } \\
\text { the Estimate }\end{array}$ \\
\hline 1 & $.102^{\mathrm{a}}$ & .010 & -.084 & .1610645022 \\
\hline
\end{tabular}

a. Predictors: (Constant), ROI1, CF1

b. Dependent Variable: RS

Menurut Sugiyono (2010) pedoman untuk memberikan interpretasi koefisien korelasi sebagai berikut:

$0.0-0.199=$ sangat rendah

$0.20-0.399=$ rendah

$0.40-0.599=$ sedang

$0.60-0.799=$ kuat

$0.80-1.000=$ ssangat kuat

Berdasarkan output diperoleh oleh angka $\mathrm{R}$ sebesar 0.102. Karena nilai korelasi ganda berada diantara $0.00-0.199$, maka dapat disimpulkan bahwa terjadi hubungan yang sangat rendah antara CF (cash flow) dan ROI (return on investment) terhadap return saham.

\section{Analisis Koefisien Deteerminasi $\left(\mathbf{R}^{2}\right)$}

Analisis determinasi digunakan untuk mengetahui presentasi sumbangan pengaruh variabel independen secara serentak terhadadap variabel dependen.Koefisien ini menunjukkan seberapa besar prosentase variasi variabel independen yang digunakan dalam model mampu menjelaskan variasi variabel dependen. $\mathrm{R}^{2}$ sama dengan 0 , maka tidak ada sedikitpun prosentase sumbangan pengaruh yang diberikan variabel independen terhadap variabel dependen, atau variasi variabel independen yang digunakan dalam model tidak menjelaskan sedikitpun variasi variabel dependen. Sebaliknya $\mathrm{R}^{2}$ sama dengan 1 , maka presentase sumbangan pengaruh yang diberikan variabel independen terhadap variabel dependen adalah sempurna.

Hasil analisis determinasi koefisien dapat dilihat pada table di bawah ini:

Tabel 4.9 Analisis Koefisien Determinasi $\left(\mathbf{R}^{2}\right)$ Model Summary

\begin{tabular}{|l|c|r|r|r|}
\hline Model & R & R Square & $\begin{array}{c}\text { Adjusted R } \\
\text { Square }\end{array}$ & $\begin{array}{c}\text { Std. Error of } \\
\text { the Estimate }\end{array}$ \\
\hline 1 & $.128^{\mathrm{a}}$ & .016 & -.077 & .1605826306 \\
\hline
\end{tabular}

a. Predictors: (Constant), ROI, CF

b. Dependent Variable: RS

Pada table 4.9 diatas analisis koefisien determinasi $\left(\mathrm{R}^{2}\right)$ didapat nilai $\mathrm{R}$ square sebesar 0.016 atau $1.6 \%$ sehingga menunjukkan bahwa presentase sumbangan pengaruh variabel independen (CF dan $\mathrm{ROI}$ ) terhadap variabel dependen (RS) ssebesar 1.6\%.Atau variasi variabel independen yang digunakan dalam model CF dan ROI mampu menjelaskan hanya sebesar $1.6 \%$ variable dependen (RS) saja. Sedangkan sisanya 
98.4\% dipengaruhi atau dijelaskan oleh variabel lain yang tidak dimasukkan ke dalam model penelitian ini.

Dari hasil regresi ini di dapat nilai std. error of the estimate sebesar -0.077 . Hal ini berarti banyaknya kesalahan dalam pediksi return saham sebesar -0.077 .

\section{Uji Hipotesis}

Uji T (parsial)

Uji ini digunakan untuk mengetahui apakah dalam model regresi variabel independen secara parsial berpengaruh signifikan terhadap variabel dependen.

Tabel 4.5.1. Uji T

Coefficients $^{\mathrm{a}}$

\begin{tabular}{|c|c|c|c|c|c|c|c|c|}
\hline \multirow{2}{*}{\multicolumn{2}{|c|}{ Model }} & \multicolumn{2}{|c|}{$\begin{array}{c}\text { Unstandardized } \\
\text { Coefficients }\end{array}$} & \multirow{2}{*}{$\begin{array}{l}\text { Standardize } \\
\text { d } \\
\text { Coefficients } \\
\text { Beta }\end{array}$} & \multirow[b]{2}{*}{$\mathrm{t}$} & \multirow{2}{*}{ Sig. } & \multicolumn{2}{|c|}{$\begin{array}{c}\text { Collinearity } \\
\text { Statistics }\end{array}$} \\
\hline & & B & Std. Error & & & & $\begin{array}{c}\text { Toleran } \\
\text { c e }\end{array}$ & VIF \\
\hline & $\begin{array}{l}\text { (Constant } \\
\text { ) }\end{array}$ & .169 & .111 & & 1.532 & .140 & & \\
\hline & CF1 & -.025 & .146 & -.040 & -.168 & .868 & .850 & 1.176 \\
\hline & ROI1 & .170 & .362 & .111 & .471 & .643 & .850 & 1.176 \\
\hline
\end{tabular}

a. Dependent Variable: RS

Pengujian Koefisien regresi variabel CF (Cash Flow)

1. Hipotesis:

- Ho: Secara parsial tidak ada pengaruh antara cash flow (CF) dengan return saham.

- Ha: Secara parsial ada pengaruh antara CF dengan return saham.

2. Menggunakan tingkat signifikansi $0.05(\alpha=5 \%)$

3. Berdasarkan output pada table 4.5.1 nilai t hitung sebesar -0.168

4. Tabel distribusi t dicari pada $\alpha=5 \%: 2$ ( uji 2 sisi ) dengan derajat kebebasan (df) n-k-1 atau 24-2-1 = 21 ( $\mathrm{n}$ adalah jumlah sample dan $\mathrm{k}$ adalah jumlah variabel independen). Dengan pengujian dua sisi (signifikansi $=0.025$ ) hasil diperoleh untuk t tabel sebesar 2.080.

5. Dengan kriteria pengujian:

- $\quad$ Ho diterima jika $-\mathrm{t}$ tabel $\leq \mathrm{t}$ hitung $\leq \mathrm{t}$ tabel $\backslash$

- Ho ditolak jika $-\mathrm{t}$ hitung $<-\mathrm{t}$ tabel atau $\mathrm{t}$ hitung $>\mathrm{t}$ tabel

Dapat kita lihat bahwa $-t$ hitung $>$-t tabel $(-0.168>-2.080)$, maka Ho diterima. Artinya secara parsial CF (Cash Flow)tidak berpengaruh terhadap return saham pada perusahaan manufaktur yang terdapat di BEI.

Hasil hipotesis diatas menunjukkan bahwa Cash Flow tidak berpengaruh signifikan terhadap return saham, Hal ini bisa saja disebabkan oleh informasi yang terkandung dalam cash flow belum sepenuhnya digunakan sebagai dasar pengambilan keputusan dalam pasar modal.

Pengujian Koefisien regresi variabel ROI (Return On Investment)

1. Hipotesis:

- Ho: Secara parsial tidak ada pengaruh antara return on investment (ROI) dengan return saham. 
- Ha: Secara parsial ada pengaruh antara return on investment (ROI) dengan return saham.

2. Menggunakan tingkat signifikansi $0.05(\alpha=5 \%)$

3. Berdasarkan output pada table 4.5.1 nilai t hitung sebesar 0.471

4. Tabel distribusi t dicari pada $\alpha=5 \%: 2$ ( uji 2 sisi ) dengan derajat kebebasan (df) $n-k-1$ atau 24-2-1 = 21 ( $\mathrm{n}$ adalah jumlah sample dan $\mathrm{k}$ adalah jumlah variabel independen). Dengan pengujian dua sisi (signifikansi $=0.025$ ) hasil diperoleh untuk t tabel sebesar 2.080.

5. Dengan kriteria pengujian:

- Ho diterima jika $-\mathrm{t}$ tabel $\leq \mathrm{t}$ hitung $\leq \mathrm{t}$ tabel

- Ho ditolak jika $-\mathrm{t}$ hitung $<-\mathrm{t}$ tabel atau $\mathrm{t}$ hitung $>\mathrm{t}$ tabel

Dapat kita lihat bahwa t hitung $<\mathrm{t}$ tabel $(0.471<2.080)$, maka Ho diterima.

Artinya secara parsial ROI (Return On Investment)tidak berpengaruh signifikan terhadap return saham pada perusahaan manufaktur yang terdapat di BEI.

Hasil uji hipotesis ini menunjukan bahwa return on investment tidak berpengaruh terhadap return saham Hasil ini manunjukkan bahwa kemungkinan para investor sudah tidak menggunakan return on investment sebagai ukuran dari kinerja perusahaan guna memprediksi returnyang akan diterimanya. Hal ini dikarenakan investasi yang ditempatkan pasa asset akan menghasilkan return yang lebih kecil dibandingkan dengan investasi yang ditempatkan pada saham (ekuitas). Sehingga menyebabkan return on investment menjadi tidak berpengaruh terhadap return saham dikarenakan pada saat ini investasi lebih banyak ditanamkan pada saham.Selain itu dapat dipengaruhi oleh faktor-faktor eksternal lainnya seperti kondisi perekonomian, data keuangan, dan lain sebagainya.

\section{Uji F (Simultan)}

Uji ini digunakan untuk mengetahui apakah variabel independen berpengaruh secara bersama-sama berpengaruh secara signifikan terhadap variabel dependen.

\section{Tabel 4.5.2. Tabel Uji F} ANOVA ${ }^{\mathrm{a}}$

\begin{tabular}{|ll|r|r|r|r|r|}
\hline \multicolumn{2}{|l|}{ Model } & \multicolumn{1}{|c|}{$\begin{array}{c}\text { Sum of } \\
\text { Squares }\end{array}$} & \multicolumn{1}{c|}{ df } & $\begin{array}{c}\text { Mean } \\
\text { Square }\end{array}$ & F & \multicolumn{1}{c|}{ Sig. } \\
\hline 1 & Regression & .009 & 2 & .005 & .175 & $.841^{\mathrm{b}}$ \\
& Residual & .542 & 21 & .026 & & \\
& Total & .551 & 23 & & & \\
\hline
\end{tabular}

a. Dependent Variable: RS

b. Predictors: (Constant), ROI, CF

Hasil uji $\mathrm{F}$ ini dapat dilihat dari output tabel 4.5.2. sebagai berikut:

1. Hipotesis:

- Ho: Tidak ada pengaruh antara Cash Flow dan Return On Investmen secara bersama-sama terhadap return saham.

- Ha: Ada pengaruh antara Cash Flow dan Return On Investmen secara bersamasama terhadap return saham.

2. Menggunakan tingkat signifikansi $0.05(\alpha=5 \%)$

3. Berdasarkan output pada table 4.5.1 nilai t hitung sebesar 0.175 
4. Menentukan $\mathrm{F}$ tabel dengan menggunakan tiingkat keyakinan $95 \%, \alpha=5 \%$, dengan df1 k-1 = 2-1 = 1 (jumlah variabel -1 ), dan dengan df $2 \mathrm{n}-\mathrm{k}-1=24-2-1=21$ (jumlah sampel-jumlah vaariabel-1), hasil diperoleh untuk $\mathrm{F}$ tabel adalah 4.325.

5. Dengan kriteria pengujian:

- Ho diterima jika Fhitung $\leq \mathrm{F}$ tabel

- Ho ditolak jika F hitung $>\mathrm{F}$ tabel

Dapat kita lihat bahwa $\mathrm{F}$ hitung $<\mathrm{F}$ tabel $(0.175<4.325)$, maka Ho diterima. Artinya secara Cash Flow dan Return On Investment secara bersama-sama tidak berpengaruh terhadap return saham yang terdapat pada perusahaan manufaktur yang terdapat di BEI.

\section{Kesimpulan}

Penelitian ini bertujuan untuk mengetahui pengaruh dari Cash Flow dan ReturnOn Investment terhadap return saham pada perusahaan manufaktur di BEI selama periode 2011-2014. Berdasarkan hasil yang diperoleh berdasarkan penelitian yang sudah dilakukan dapat diambil kesimpulan sebagai berikut:

1. Hasil pengujian berdasarkan uji t menunjukkan bahwa cash flow tidak berpengaruh secara signifikan terhadap return saham. Hsil penelitian ini konsisten dengan penelitian yang dilakukan oleh Suariani Ginting (2012).

2. Hasil pengujian berdasarkan uji t menunjukkan bahwa return on investment tidak berpengaruh terhadap return saham. Hasil penelitian ini konsisten dengan penelitian yang dilakukan oleh Ruriana Ulfa (2011).

3. Hasil pengujian berdasarkan uji $\mathrm{f}$ menunjukkan bahwa cash flow dan return on investment secara simultan tidak berpengaruh terhadap return saham. Hal ini disebabkan karena variabel yang diambil oleh peneliti bukan bagian dari faktorfaktor yang dapat mempenaruhi return saham. Selain itu bisa dipengaruhi oleh faktor-faktor eksternal yang membuat investor tidak menggunakan cash flow dan ROI sebagai pertimbangan atau perhitungan dari return saham yang diperolehnya atas investasi.

\section{Ketebatasan Penelitian}

a. Keterbatasan dalam penelitian ini adalah dimana variabel yang digunakan hanya terbatas pada sebagian variabel akuntansi saja. Dari hasil pengujian dilihat bahwa variabel independen yang digunakan dalam model sangat kecil bahkan tidak memiliki pengaruh terhadap variabel dependen dan sebagian besar variabel dependennya dipengaruhi oleh variabel lain diluar model regresi.

b. Keterbatasan penelitian ini dalam pengambilan sampel perusahaan yang hanya sebagian kecil perusahaan manufaktur dan jumlah periode tahun yang terlalu singkat sehingga tidak mencerminkan reaksi dari pasar modal.

\section{Saran}

a. Dari hasil penelitian ini diharapkan pada penelitian selanjutnya agar memperluas variabel independen karena dari hasil penelitian masih banyak variabel-variabel lain diluar model yang memiliki pengaruh terhadap return saham.

b. Dari hasil penelitian ini diharapkan untuk penelitian selanjutnya agar menambah atau memperbanyak jumlah sampel perusahaanmanufaktur agar bisa mencerminkan reaksi pasar modal secara keseluruhan dan memperpanjang periode tahun penelitian agar pada hasil penelitian dapat mewakili kondisi perusahaan manufaktur tersebut. 
c. Bagi investor diharapkan hasil penelitian ini sebagai bahan pertimbangan dalam melakukan investasi dengan melihat kondisi keuangan perusahaan melalui rasio keuangan khususnya melalui rasio Return On Invesment (ROI), dan sedikitnya melihat pertimbangan melalui laporan aru kas perusahaan.

\section{DAFTAR PUSTAKA}

Amalia, Henny Septiana. 2010. Analisis Pengaruh Earning Per Share, Return On Investment dan Debt To Equity Ratio Terhadap Harga Saham Perusahaan Farmasi di Bursa Efek Indonesia. Skripsi. Banjarmasin: Sekolah Tinggi Ilmu Ekonomi Indonesia Banjarmasin.

Ang, Robert. 1997. Buku Pintar Pasar Modal Indonesia. Jakarta: Mediasoft Indonesia.

Ardiansyah, Asrul dkk. 2011. "Hubungan Informasi Arus Kas dan Return On Investment Terhadap Return Saham”. Makassar: Universitas Hasanuddin.

Daniati, Ninna, dan Suhairi. 2006. "Pengaruh Kandungan Informasi Komponen Laporan Arus Kas, Laba Kotor, Siza Perusahaan Terhadap Expected Return Saham". Makalah SNA IX.

Edi Susilo, Petrus Dwi. 2010. "Pengaruh Laba Kotor, Total Arus Kas, dan Size Perusahaan terhadap Return Saham Perusahaan Food and Beverages Yang Terdaftar di Bursa Efek Indonesia. Skripsi. Depok: Fakultas Ekonomi, Universitas Gunadarma.

Fuady, Munir. 2001. Pasar Modal Modern (Tinjauan Hukum). Catatan Kedua. Bandung: Citra Aditya Bakti.

Ghozali, Imam. 2005. Aplikasi Analisis Multivariate dengan program SPSS. Semarang: BP UNDIP.

Ginting, Suriani. 2012. "Analisis Pengaruh Pertumbuhan Arus Kas dan Profiitabilitas terhadap Return Saham Pada Perusahaan LQ45 di BEI”. Medan: STIE Mikroskil. 98

Hartono, Jogiyanto. 2010. Teori Portofolio dan Analisis Investasi. Edisi Ketujuh. Yogyakarta: BPFE

Jodi Utomo, Seno. 2011. Analisis Pengaruh Arus Kas Operasi dan Laba Akuntansi terhadap Return Saham Perusahaan Manufaktur di Bursa Efek Indonesia. Semarang: Universitas Semarang.

Kansil dan Christine. 2002. Pokok-Pokok Hukum Pasar Modal.Cetakan Kedua. Jakarta: Pustaka Sinar Harapan.

Kasmir. 2008. Analisis Laporan Keuangan. Edisi pertama. Yogyakarta: AMP YKPN Pradhono dan Yulius Jogi. 2004. "Pengaruh Economic Value Added, Residual Income, Earnings, dan Arus Kas Operasi terhadap Return Saham Yang Diterima Oleh Pemegeng Saham (Studi Pada Perusahaan Manufaktur di BEI)”. Jurnal Ilmiah. Jakarta: Jurnal Akuntansi Keuangan.

Prastowo, Dwi dan Julianty, Rifka. 2002. “Analisis Laporan Keuangan”. Cetakan Kedua. Yogyakarta: AMP YKPN.

Priyatno, Duwi. 2010. "Paham Analisa Statistik Data dengan SPSS”. Yogyakarta: Mediakom.

Sinaga, Hariono. 2010. "Pengaruh total arus kas, komponen arus kas, laba akuntansi terhadap return saham. Universitas Diponegoro: Semarang.

SR, Soemarso. 2005. Akuntansi Suatu Pengantar. Buku 2 Edisi Ketiga. Jakarta:

Salemba Empat. 
Sunariah, Siti. 2003. "Pengantar Pengetahuan Pasar Modal”. Yogyakarta: UUP AMP YKPN.

Syahrial Dermawan dan Djahotman Purba. 2013. Analisis Laporan Keuangan: Cara Mudah dan Praktis Memahami Laporan Keuangan. Catatan kedua. Jakarta: Mitra Wacana Media.

Trisaeni, Dyah Kumala. 2007. "Pengaruh Kinerja Keuangan terhadap Return Saham pada Perusahaan Manufaktur di Bursa Efek Indonesia (BEI)”. Skripsi. Yogyakarta: Fakultas Ekonomi Universitas Islam Indonesia.

Ulfa, Ruriana. 2011. "Pengaruh Ukuran Perusahaan, Leverage, Economic Value Added, ROI, dan EPS Terhadap Return Yang di Terima Pemegang Saham. Jurnal Ilmiah. Universitas Islam Negeri Syarif Hidayatullah: Tangerang.

www.finance.yahoo.com Historical Harga Saham diakses oleh Yunia Asmanah Kurniasih pada tanggal 15 Juni 2015 pukul 11:32 WIB.

www.idx.co.id. Daftar Nama Perusahaan dan Laporan Keuangan Perusahaan. Diakses oleh Yunia Asmanah Kurniasih pada tanggal 13 Juni 2015 pukul 15:20 WIB. 